\title{
Особенности межличностных отношений с отцом у девушек, страдающих любовной аддикцией
}

\author{
Надежда А. Цветкова ${ }^{1,2 *}$, Анна И. Рыбакова' \\ ${ }^{1}$ Российский государственный социальный университет, г. Москва, Российская \\ Федерация \\ 2 ФКУ НИИ ФСИН России, г. Москва, Российская Федерация \\ *E-mail: TsvetkovaNA@yandex.ru
}

\section{Аннотация}

Ввеление. Статья посвящена анализу особенностей межличностных отношений с отцами Аевушек 16-19 ^ет, страдающих любовной аАликцией. ПреАставлен обзор публикаций по проблеме и обусловливающим ее фракторам, главным из которых указывается роль отца. Эмпирические данные получены в процессе психологического консультирования Аевушек-^юбовных аАликтов. Научная новизна состоит в конкретизации характера межличностных отношений Аочерей, страАающих Аюбовной аААикцией, с отцами и в вывоАах относительно профрилактики этой зависимости у новых поколений россиянок.

Метолы. Использовались: психологическое тестирование (тест ююбовной аААикции А.Ю. Егорова; тест межличностной зависимости Р. Гиршфильда; методика «ПоР» А.И. Вассермана, И.А. Горьковой, Е.Е. Ромицыной; методика «Семейная социограмма» Э.Г. Эйдемиммера и О.В. Черемисина; методика оценки отношений Аочери с отцом; методика самооценки «я в отношениях с мужчинами в глазах Аругих ^юлей»); математико-статистическая обработка данных (осуществлена с помощью пакета SPSS Statistics 22: корреляционный анализ Аанных выполнен по методу Спирмена, сравнительный - по критерию Манна - Уитни).

Результаты. Представлены результаты сравнительного анализа особенностей межличностных отношений с отцами Аевушек - любовных аААиктов и Аевушек, не имеющих признаков патологической ^юбви. Приведены результаты корреляционного анализа данных, показывающие, что с возрастом у Аевушек, не страАающих Аюбовной аААикцией, межличностная зависимость снижается, тогАа как у Аевушек - Аюбовных аААиктов она усиливается.

ОбсужАение результатов. Проинтерпретированы отношения Аевушек - ^юбовных аААиктов с отцами. Показано, что они часто характеризуются Аирективностью отца, его непоследовательностью и вражАебностью, но позитивным интересом Аочери к нему; фризически отсутствующий, безучастный или неадекватный в своем участии отец (Аирективный, непослеАовательный, вражАебный) является фрактором формирования Аюбовной алдикции у Аочери. Предлагается смещение акцента 


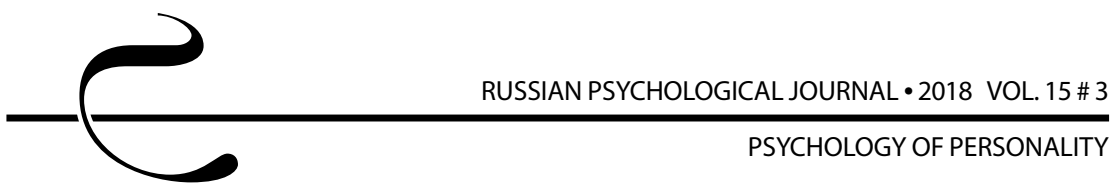

с коррекции ^юбовной аААикции на ее социально-психологическую профилактику у новых поколений россиянок.

\title{
КАючевые слова
}

Аочери, отцы, характер отношений, отцовская Аепривация, ^юбовная аАликция, непоследовательность отца, Аирективность отца, враждебность отца, отстраненность отца, психологическая помощь

\section{Основные положения}

- Аевушки - любовные алАикты чаще всего воспитываются в неполных семьях и часто ^ишены возможности полноценно общаться с родными отцами;

- Аевушки - ююбовные аАликты невысоко оценивают вовлеченность родного отца в их жизнь и качество отношений с ним;

- межличностные отношения Аевушек - ^юбовных аАликтов с отцами характеризуются со стороны Аочерей позитивным интересом, а со стороны отцов (если они участвуют в воспитании Аочери) - Аирективностью, непослеАовательностью и вражАебностью;

- фрактором фрормирования любовной аАликции у Аочери является отсутствующее, безучастное или неалекватное (непоследовательное, Аирективное, враждебное) в своем участии отцовство.

\section{Для цитирования}

Цветкова Н. А., Рыбакова А.И. Особенности межличностных отношений с отцом у девушек, страдающих любовной аддикцией // Российский психологический журнал. 2018. T. 15, № 3. C. 116-142. DOI: 10.21702/rpj.2018.3.6

Материалы статьи получены 08.01.2018

UDC 159.96

DOI: $10.21702 /$ rpj.2018.3.6

\section{Characteristics of Interpersonal Relationships Between Girls Suffering From Love Addiction and Their Fathers}

\author{
Nadezhda A. Tsvetkova ${ }^{1,2^{*}}$, Anna I. Rybakova ${ }^{1}$ \\ ${ }^{1}$ Russian State Social University, Moscow, Russian Federation \\ ${ }^{2}$ Federal State Institution Research Institute of the Federal Penitentiary Service of Russia, \\ Moscow, Russian Federation \\ *Corresponding author. E-mail: TsvetkovaNA@yandex.ru
}




\begin{abstract}
Introduction. The paper (a) examines the characteristics of interpersonal relationships between 16-19-year-old girls suffering from love addiction and their fathers and (b) provides an overview of previous studies on the issue. In the latter, the father's role is recognized to be among its major contributing factors. Empirical data were collected during psychological counseling of young female love addicts. The present study focuses on the nature of interpersonal relationships between daughters suffering from love addiction and their fathers and discusses preventive measures against such dependency in new generations of Russian females.
\end{abstract}

Methods. These were (a) the Love Addiction Test by A. Yu. Egorova; (b) the Interpersonal Dependency Inventory by R. Hirschfeld; (c) the Teenagers About Parents technique by L.I. Wasserman, I. A. Gor'kova, and E.E. Romitsyna; (d) the Family Sociograms by E.G. Eidemiller and O.V. Cheremisin; (e) the technique for assessing father-daughter relationships; ( $f$ ) the My Relations with Men in the Eyes of Others self-assessment technique. Statistical procedures for data processing included Spearman's correlation and Mann-Whitney U test.

Results. The study presents the results of comparative analysis of father-daughter relationships in two study groups - young female love addicts and those having no signs of pathological love. The findings suggest that with age interpersonal dependency decreases in girls not suffering from love addiction and increases in young female love addicts.

Discussion. The study seeks to describe, understand, and interpret interpersonal relationships between young female love addicts and their fathers. These are often characterized by fathers' directivity, inconsistency, and hostility, but at the same time by daughters' positive interest in their fathers. A physically absent, indifferent or inadequate in his care father (i. e., directive, inconsistent, and hostile) is a factor inducing formation of a daughter's love addiction. The authors suggest shifting emphasis from the correction of love addiction to its socio-psychological prevention in new generations of Russian females.

\title{
Keywords
}

daughters, fathers, characteristics of relationships, paternal deprivation, love addiction, father's inconsistency, father's directivity, father's hostility, father's estrangement, psychological help

\section{Highlights}

- Young female love addicts are most often brought up in single-parent families and are often deprived of the opportunity to fully communicate with their fathers.

- Young female love addicts report a low level of their biological fathers' involvement in their lives and the low-quality relationships with their fathers. 


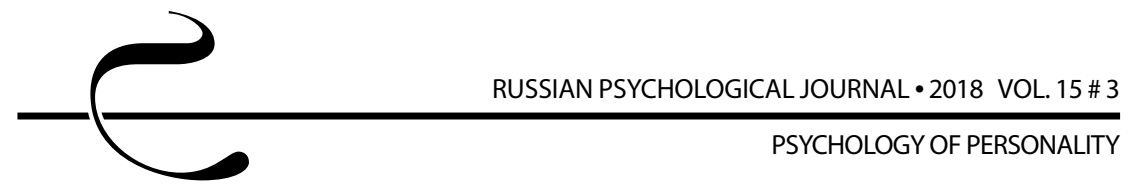

Interpersonal relationships between young female love addicts and their fathers are characterized by daughters' positive interest and fathers' directivity, inconsistency, and hostility (if they are involved in the upbringing of their daughters).

- Absent, indifferent or inadequate fathering (i. e., directive, inconsistent, and hostile) is a factor inducing formation of a daughter's love addiction.

\section{For citation}

Tsvetkova N. A., Rybakova A.I. Characteristics of Interpersonal Relationships Between Girls Suffering From Love Addiction and Their Fathers. Rossiiskii psikhologicheskii zhurnal - Russian Psychological Journal, 2018, V. 15, no. 3, pp. 116-142 (in Russian). DOI: 10.21702/rpj.2018.3.6

Original manuscript received 08.01.2018

\section{Введение}

В научной литературе любовная аддикция (патологическая любовь) описывается как отношения, характеризующиеся сильной страстью, плохо контролируемым поведением, а также навязчивой эмоциональной фиксацией на другом человеке, ненасытной потребностью в любви, непомерными требованиями к партнеру, патологической ревностью. Любовные аддикты опекают и контролируют своих партнеров, фокусируют всю свою энергию на них и их проблемах, при этом отрицают наличие каких-либо проблем у себя; как правило, они имеют низкую самооценку, подавляют собственные чувства, ищут счастье вне самих себя, склонны проявлять пассивную агрессию, постоянно чувствуют гнев, страх, стыд; у них слабые личностные границы; они не доверяют ни себе, ни другим людям; они обвиняют, угрожают, заставляют, умоляют, подкупают, манипулируют, советуют $[1,2,3,4,5,6]$.

По некоторым обобщенным данным зарубежных исследований, приведенным А. Ю. Егоровым в 2015 г., доля любовных аддиктов в молодежной среде составляет около четверти популяции [по 1]. Немногочисленные публикации позволяют предполагать, что в формировании любовной аддикции у дочери большую роль играют ее отношения с отцом: они показывают пример межполовых контактов и взаимодействия, влияют на характер общения дочери с мужчинами и будущими партнерами по длительным любовным взаимоотношениям и браку. Теплые и приносящие удовлетворение отношения с отцом развивают в дочери женственность и уверенность в себе, способствуют более легкой гетеросексуальной адаптации. Кроме того, отец может влиять и на результат разрешения ею экзистенциальной дилеммы: семья или карьера? Недостаточное проявление отцовской любви вызывает у дочери тревогу, нестабильность настроения и капризы $[2,7,8,9,10,11]$. 
В случае отсутствия отца или его отчужденности от дочери возникает отцовская (патернальная) депривация. Она приводит к тому, что девочка начинает считать себя нелюбимой, «не заслуживающей любви» и в итоге, став взрослой, оказывается не способной переживать подлинную близость с мужчиной и от этого испытывает разочарование и боль $[8,11,12,13,14,15]$.

Однако диапазон современного российского отцовства достаточно широк: его полюса простираются от отчуждения (полной отстраненности от дочери) до симбиоза (безграничного слияния в межличностных отношениях с ней). Хотя в поле зрения исследователей попала и другая крайность современного отцовства - симбиоз, «когда слишком много любви» [3, 16], тем не менее, исследователи гораздо чаще отмечают дефицит общения и взаимодействия отца и дочери даже в полных российских семьях (по причине постоянной занятости или нежелания общаться отец не уделяет ей должного внимания и формально выполняет свою отцовскую роль) [7, 12, 14 и др.].

В обзорной статье А.Ю. Егорова приводятся современные данные о клинических проявлениях, диагностике, эпидемиологии, психологическом профиле, гендерных особенностях любовной аддикции («патологической любви»). Вслед за И.Н. Хмаруком он также отмечает важность изучения этой проблемы по той причине, что она приводит к неблагоприятным для человека последствиям - вызывает быструю десоциализацию личности, увеличивает интенсивность проявления аутодеструктивных и аутоагрессивных тенденций в поведении, способствует повышению уровня суицидального риска, способствует виктимизации личности [1].

К настоящему времени достаточно полно раскрыты следующие аспекты этой проблемы: 1) сущность, характерные признаки и виды любовной аддикции [1, 2, 6, 27, 30 и др.]; 2) социально-психологическая обусловленность формирования любовной аддикции $[2,4,9,15,16,17,18,19,20,21,22,23$, 24, 25 и др.]; 3) коррекция и профилактика любовной аддикции [3, 5, 7, 8, 21, 25, 26, 27, 28, 29 и др.]; в этом направлении продолжается поиск эффективных методов работы с «любовными аддиктами». Однако он «сдерживается отсутствием единого понимания природы, психопатологии и клинической динамики этого расстройства» [30, с. 17]. Например, А. Лорена с коллегами в случаях «патологической любви» практикуют аналитически ориентированную психодраму, нацеленную на достижение инсайтов, повышающих самооценку любовных аддиктов и продвигающих их по пути установления здоровых межличностных отношений с партнерами [1, с. 80; 6]. Наиболее известными в России зарубежными подходами в оказании психологической помощи клиентам, страдающим любовной аддикцией, являются: а) 10-шаговая программа Р. Норвуд (она предлагает схему «падения» при любовной аддикции и «возрождения» при исцелении от нее [8]); б) алгоритм работы 


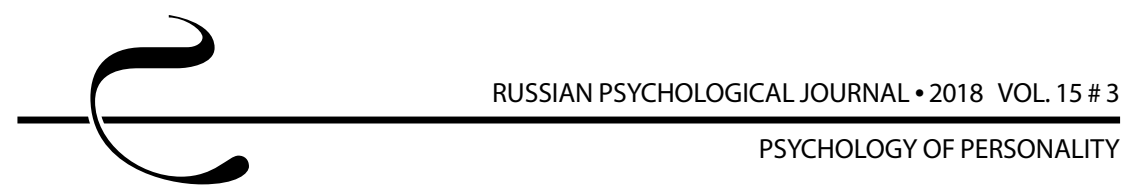

для исцеления от любовной зависимости М. Битти [26]; в) эволюционный подход (расширенный 12-шаговый процесс) Б. Уайнхолда и Д. Уайнхолд к выздоровлению от созависимости [5] и др. Отечественные практические психологи для этих целей применяют психологический тренинг и группы поддержки (В.Д. Москаленко, А.В. Пилипенко, И.А. Соловьева и др.).

К настоящему времени в зарубежной и отечественной научной литературе раскрыта роль отца в воспитании детей $[7,10,11,13,14,31$ и др.]; выделены типы отцовской любви, выявлены признаки и факторы формирования патернальной депривации, в т. ч. патернальной депривации дочери [7, 10, 11, 12, 13, 14, 22, 32 и др.]; изучена взаимосвязь детско-родительских взаимоотношений с выбором брачного партнера [17, 21, 23, 33 и др.]; выделены факторы деструктивной привязанности взрослой женщины к партнеру-мужчине, среди которых патернальная депривация, а также раскрыты некоторые условия совладания с нею $[5,7,8,21,26,29,30,32,34,35$ и др.]. В целях коррекции отцовской депривации предпочтение отдается методам трансакционного анализа (М. Руфлер; В. Каппони и Т. Новак и др.), которые позволяют клиентам стать для себя самих Родителем, Ребенком и Взрослым и таким образом отказаться от поиска зависимых отношений в любви.

Любовная аддикция в связи с отцовской депривацией впервые анализируется в статье Е.П. Шалаевой [9] на выборке из 76 девушек в возрасте от 15 лет до 31 года. С ее точки зрения, коррекция любовной аддикции будет более эффективной, если социально-психологическая работа с девушками, в первую очередь, будет направлена на коррекцию признаков любовной аддикции - низкой самооценки, нарушенных личностных границ, запрета на выражение негативных чувств, а также на прощение и принятие отца таким, какой он есть.

Цель нашего исследования - анализ характера межличностных отношений с отцом у девушек, страдающих любовной аддикцией, и поиск связи между особенностями отцовства и любовной аддикцией у дочерей для последующей разработки стратегии психологической помощи.

\section{Методы}

Исследование проводилось в г. Москве. Выборку составили 103 девушки 16-19 лет, поделенные на две группы: I (экспериментальная) группа - девушки, страдающие любовной аддикцией (24 студентки 1-2 курсов Российского государственного социального университета и 29 девушек, в 2015-2017 гг. обращавшихся в консультацию за психологической помощью с жалобами на сильную душевную боль и трудности самоконтроля (со слов девушек, они много вкладывали в эти отношения, но слишком мало получали взамен или получили то, чего никак не желали получить, но до сих пор не могут 
забыть своих «обидчиков»)); II (контрольная) группа - 50 девушек-клиенток психолога, обращавшихся за помощью с другими типами психологических проблем и не имеющих любовной зависимости (она определялась по тесту любовной аддикции А.Ю. Егорова).

Таблица 1. Общая характеристика экспериментальной и контрольной групп

Table 1. General characteristics of experimental and control groups

\begin{tabular}{|c|c|c|}
\hline $\begin{array}{c}\text { Показатели } \\
\text { Characteristics }\end{array}$ & $\begin{array}{c}\text { Экспериментальная } \\
\text { группа (53 чел.) } \\
\text { Experimental group } \\
(n=53)\end{array}$ & $\begin{array}{l}\text { Контрольная } \\
\text { группа (50 чел.) } \\
\text { Control group } \\
(n=50)\end{array}$ \\
\hline $\begin{array}{l}\text { Особенности семейного } \\
\text { воспитания } \\
\text { Characteristics of family } \\
\text { upbringing }\end{array}$ & $\begin{array}{c}\text { чел./\% } \\
\text { subjects } / \%\end{array}$ & $\begin{array}{c}\text { чел./\% } \\
\text { subjects } / \%\end{array}$ \\
\hline $\begin{array}{l}\text { Полная семья } \\
\text { Intact family }\end{array}$ & $25(47,2 \%)$ & 34 (68\%) \\
\hline $\begin{array}{l}\text { Полная семья } \\
\text { Ао подросткового возраста } \\
\text { Intact family until adolescence }\end{array}$ & $4(7,5 \%)$ & $3(6 \%)$ \\
\hline $\begin{array}{l}\text { Воспитывались матерью } \\
\text { Brought up by mothers }\end{array}$ & $10(18,9 \%)$ & $10(20 \%)$ \\
\hline $\begin{array}{l}\text { Воспитыва^ись отцом } \\
\text { Brought up by fathers }\end{array}$ & $2(3,8 \%)$ & 0 \\
\hline $\begin{array}{l}\text { Воспитывались матерью } \\
\text { и отчимом } \\
\text { Brought up by mothers and } \\
\text { stepfathers }\end{array}$ & $6(11,3 \%)$ & 0 \\
\hline $\begin{array}{l}\text { Аругие варианты } \\
\text { Other variants }\end{array}$ & $6(11,3 \%)$ & 0 \\
\hline
\end{tabular}




\begin{tabular}{|c|c|c|}
\hline $\begin{array}{l}\text { Опыт общения с мужчинами } \\
\text { (среднее значение по группе, } \\
\text { число случаев) } \\
\text { Experience of relationships with } \\
\text { men (mean score for the group, } \\
\text { number of cases) }\end{array}$ & 2,3 & 2,0 \\
\hline $\begin{array}{l}\text { Алительность Аюбовных } \\
\text { отношений (среднее } \\
\text { значение, в месяцах) } \\
\text { Duration of love relationships } \\
\text { (mean score, months) }\end{array}$ & 18,4 & 9,7 \\
\hline $\begin{array}{l}\text { Продолжительность } \\
\text { страданий после разрыва } \\
\text { отношений (среднее } \\
\text { значение) } \\
\text { Duration of suffering after } \\
\text { a relationship breakup (mean } \\
\text { score) }\end{array}$ & 2,1 & 0,8 \\
\hline & $\begin{array}{c}\text { чел./\% } \\
\text { subjects/\% }\end{array}$ & $\begin{array}{c}\text { чел./\% } \\
\text { subjects } / \%\end{array}$ \\
\hline $\begin{array}{l}\text { В течение } 1 \text { месяца } \\
\text { For a month }\end{array}$ & $5(9,4 \%)$ & 41 (82\%) \\
\hline $\begin{array}{l}\text { В течение нескольких месяцев } \\
\text { For several months }\end{array}$ & 38 (71,7\%) & 9 (18\%) \\
\hline $\begin{array}{l}\text { Больше } 1 \text { гола } \\
\text { Over a year }\end{array}$ & 10 (18,9\%) & 0 \\
\hline
\end{tabular}




\begin{tabular}{|c|c|c|}
\hline $\begin{array}{l}\text { Причины разрыва отношений } \\
\text { Reasons for a relationship } \\
\text { breakup }\end{array}$ & $\begin{array}{c}\text { чел./\% } \\
\text { subjects } / \%\end{array}$ & $\begin{array}{c}\text { чел./\% } \\
\text { subjects/\% }\end{array}$ \\
\hline $\begin{array}{l}\text { «рудности общения, } \\
\text { непонимание» } \\
\text { "Communication difficulties, } \\
\text { misunderstanding" }\end{array}$ & $4(7,5 \%)$ & $7(14 \%)$ \\
\hline $\begin{array}{l}\text { «астые ссоры, неуважение } \\
\text { ко мне, грубосты» } \\
\text { "Frequent quarrels, disrespect, } \\
\text { and roughness" }\end{array}$ & $5(9,4 \%)$ & 0 \\
\hline $\begin{array}{l}\text { «Употребля^ алкоголь } \\
\text { и наркотики» } \\
\text { "Used alcohol and drugs" }\end{array}$ & $2(3,8 \%)$ & 0 \\
\hline $\begin{array}{l}\text { "Измена, предательство, ^ожь» } \\
\text { "Treason, betrayal, and lie" }\end{array}$ & $10(18,9 \%)$ & 0 \\
\hline $\begin{array}{l}\text { «Поросли и поняли, что мы } \\
\text { не пара» } \\
\text { "We grew up and realized that } \\
\text { we had never been a couple" }\end{array}$ & 1 (1,9\%) & 0 \\
\hline $\begin{array}{l}\text { "Он использова^ меня» } \\
\text { "Hе used me" }\end{array}$ & $2(3,8 \%)$ & 0 \\
\hline $\begin{array}{l}\text { «Поняли, что мы разные» } \\
\text { "We understood that we were } \\
\text { different" }\end{array}$ & $7(13,2 \%)$ & 0 \\
\hline $\begin{array}{l}\text { «Затрудняюсь ответить» } \\
\text { "It is difficult to answer" }\end{array}$ & $22(41,5 \%)$ & 23 (46\%) \\
\hline
\end{tabular}




\begin{tabular}{|c|c|c|}
\hline $\begin{array}{l}\text { "Он-бабник» } \\
\text { "He's a womanizer" }\end{array}$ & 0 & $6(12 \%)$ \\
\hline $\begin{array}{l}\text { "Моя мама не одобряла наши } \\
\text { отношения» } \\
\text { "Му mother didn't approve of } \\
\text { our relationships" }\end{array}$ & 0 & $3(6 \%)$ \\
\hline $\begin{array}{l}\text { «Расстояние (мы жили в разных } \\
\text { городах)» } \\
\text { "Distance (we lived in different } \\
\text { cities)" }\end{array}$ & 0 & $2(4 \%)$ \\
\hline $\begin{array}{l}\text { «РяАОМ С ним я чувствовала } \\
\text { неудобство» } \\
\text { "I felt uncomfortable around } \\
\text { him" }\end{array}$ & 0 & $2(4 \%)$ \\
\hline $\begin{array}{l}\text { "Он не зна^, чего хочет» } \\
\text { "He didn't know what he } \\
\text { wanted" }\end{array}$ & 0 & $2(4 \%)$ \\
\hline $\begin{array}{l}\text { «рошла симпатия» } \\
\text { "Sympathy has gone" }\end{array}$ & 0 & $2(4 \%)$ \\
\hline $\begin{array}{l}\text { «У нас оказались разные } \\
\text { интересы и цели в жизни» } \\
\text { "We had different interests and } \\
\text { goals in life" }\end{array}$ & 0 & $1(2 \%)$ \\
\hline $\begin{array}{l}\text { «Он не Аари^ никаких } \\
\text { подарков» } \\
\text { "Не didn'† give me any presents" }\end{array}$ & 0 & $1(2 \%)$ \\
\hline $\begin{array}{l}\text { «Мы ма^о общались наедине» } \\
\text { "We didn't talk much alone" }\end{array}$ & 0 & $1(2 \%)$ \\
\hline
\end{tabular}


В ходе исследования использовались следующие методы и методики:

1. Методы социально-психологической диагностики:

1) тест на выявление любовной аддикции А.Ю. Егорова [36];

2) тест на межличностную зависимость (любовную, от партнера, в детско-родительских отношениях) Р. Гиршфильда в адаптации О.П. Макушиной, имеющий 3 шкалы: а) эмоциональная опора на других; б) неуверенность в себе; в) стремление к автономии [37];

3) методика «Подростки о родителях» (ПоР) Л.И. Вассермана, И.А. Горьковой, Е.Е. Ромицыной, включающая пять шкал (позитивный интерес, директивность, враждебность, автономность, непоследовательность), по которым составлялось представление об образе отца в глазах дочери [38];

4) методика «Семейная социограмма» Э.Г. Эйдемиллера и О.В. Черемисина, позволяющая выявить характер межличностных отношений дочери и отца в семейной системе [39];

5) методика самооценки «Я в отношениях с мужчинами в глазах других людей», дающая возможность изучить оценку дочери себя со стороны и своей успешности в отношениях с мужчинами. Она состоит из одного вопроса (Если бы Вы смотрели на себя со стороны глазами других людей, то какое из высказываний могло бы относиться к Вам?) с 6-ю вариантами ответа (0 - «Здесь нет такой фразы, которая обо мне»; 1 - «Она хорошая девочка, но ей не везет в любви»; 2 - «Она плохая девочка, но ее любит хороший парень»; 3 - «Она плохая девочка, но парни за ней табуном ходят»; 4 - «Она хорошая девочка и пользуется повышенным вниманием парней»; 5 - «Она хорошая девочка и дружит с таким же хорошим парнем»);

6) методика оценки отношений дочери с родным отцом и его вовлеченности в воспитание (применялась 10-балльная шкала - от 10 (отец всегда живо и с интересом реагировал на то, что происходило с дочерью) до 1 (отец практически не участвовал в воспитании дочери)).

2. Методы математико-статистической обработки данных с использованием пакета SPSS Statistics 22 (проверка достоверности различий между группами проведена по критерию Манна - Уитни, корреляционный анализ данных выполнен по методу Спирмена).

\section{Результаты}

С помощью теста выявления любовной аддикции А. Ю. Егорова установлено, что девушки экспериментальной группы (далее - ЭГ-53 чел.) различны по уровням любовной аддикции: высокий уровень имели 6 девушек (11,3 \%), средний - 47 чел. (88,7\%); девушек с низким уровнем любовной аддикции не обнаружено. У девушек контрольной группы (далее - КГ-50 чел.) какиелибо признаки любовной аддикции данный тест не выявил. Проверка 
достоверности различий по критерию Манна - Уитни показала, что по признаку любовной аддикции ЭГ и КГ достоверно различаются (U = 0,0 при $\mathrm{p}=0,000)$.

Результаты, полученные по тесту межличностной зависимости Р. Гиршфильда, сведены в таблицу 2 и представлены на рисунке 1.

Таблица 2. Показатели межличностной любовной зависимости у Аевушек экспериментальной и контрольной групп

Table 2. Interpersonal love addiction in girls from experimental and control groups

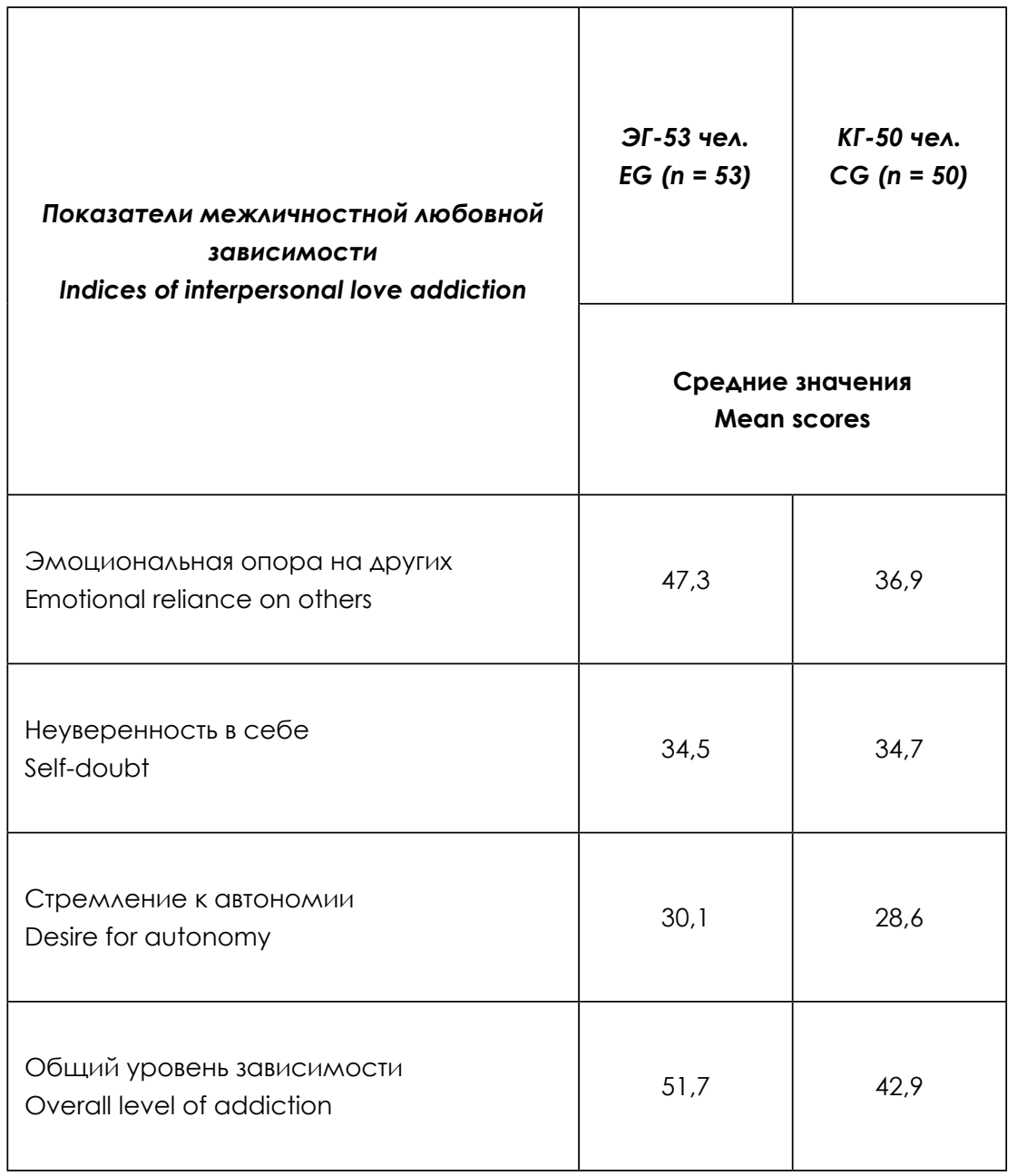




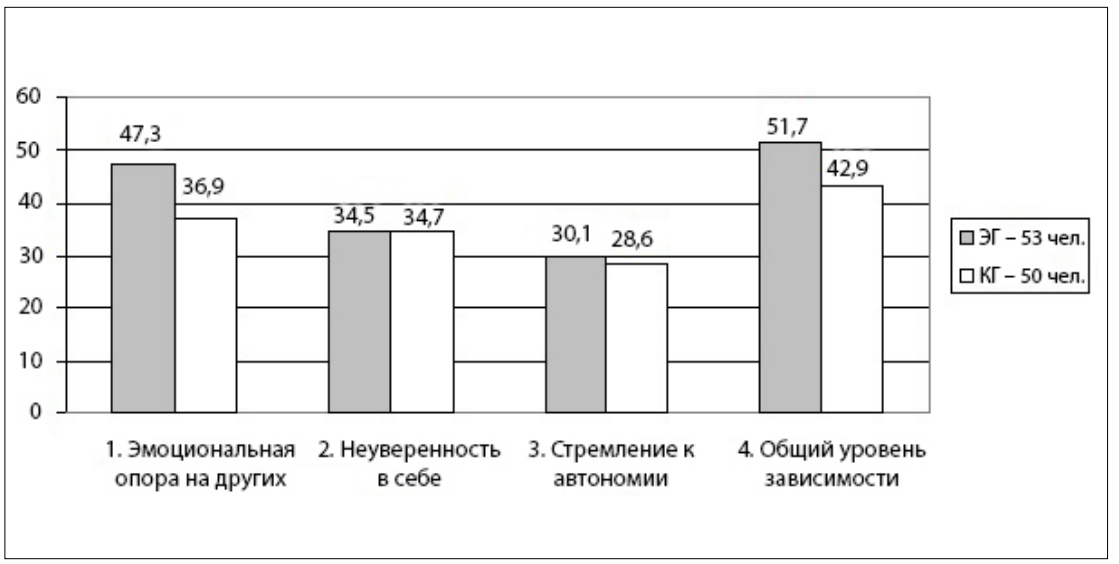

Рисунок 1. Показатели межличностной ^юбовной зависимости у Аевушек экспериментальной и контрольной групп

Figure 1. Interpersonal love addiction in girls from experimental and control groups

Результаты, полученные по методике «Подростки о родителях» (ПоР) Л.И. Вассермана, И. А. Горьковой, Е.Е. Ромицыной, представлены ниже в таблице 3 и на рисунке 2.

Таблица 3. Показатели образа отца в глазах дочери

Table 3. Indices of a father's image in his daughter's eyes

\begin{tabular}{|c|c|c|}
\hline Показатели образа отца в глазах Аочери & $\begin{array}{l}\text { ЭГ- } 53 \text { чел. } \\
E G(n=53)\end{array}$ & $\begin{array}{l}K \Gamma-50 \text { чел. } \\
C G(n=50)\end{array}$ \\
\hline & \multicolumn{2}{|c|}{$\begin{array}{l}\text { Сренние значения } \\
\text { Mean scores }\end{array}$} \\
\hline $\begin{array}{l}\text { Позитивный интерес к отцу } \\
\text { Positive interest in a father }\end{array}$ & 2,6 & 2,6 \\
\hline $\begin{array}{l}\text { Аирективность отца } \\
\text { Father's directivity }\end{array}$ & 2,8 & 1,8 \\
\hline
\end{tabular}




\begin{tabular}{|c|c|c|}
\hline Показатели образа отца в глазах дочери & $\begin{array}{l}\text { ЭГ-53 чел. } \\
E G(n=53)\end{array}$ & $\begin{array}{l}\text { КГ-50 чел. } \\
C G(n=50)\end{array}$ \\
\hline & \multicolumn{2}{|c|}{$\begin{array}{l}\text { Средние значения } \\
\text { Mean scores }\end{array}$} \\
\hline $\begin{array}{l}\text { Вражлебность отца } \\
\text { Father's hostility }\end{array}$ & 2,5 & 2,0 \\
\hline $\begin{array}{l}\text { Автономность отца } \\
\text { Father's isolation }\end{array}$ & 2,9 & 3,0 \\
\hline $\begin{array}{l}\text { Непоследовательность отца } \\
\text { Father's inconsistency }\end{array}$ & 3,0 & 2,4 \\
\hline
\end{tabular}

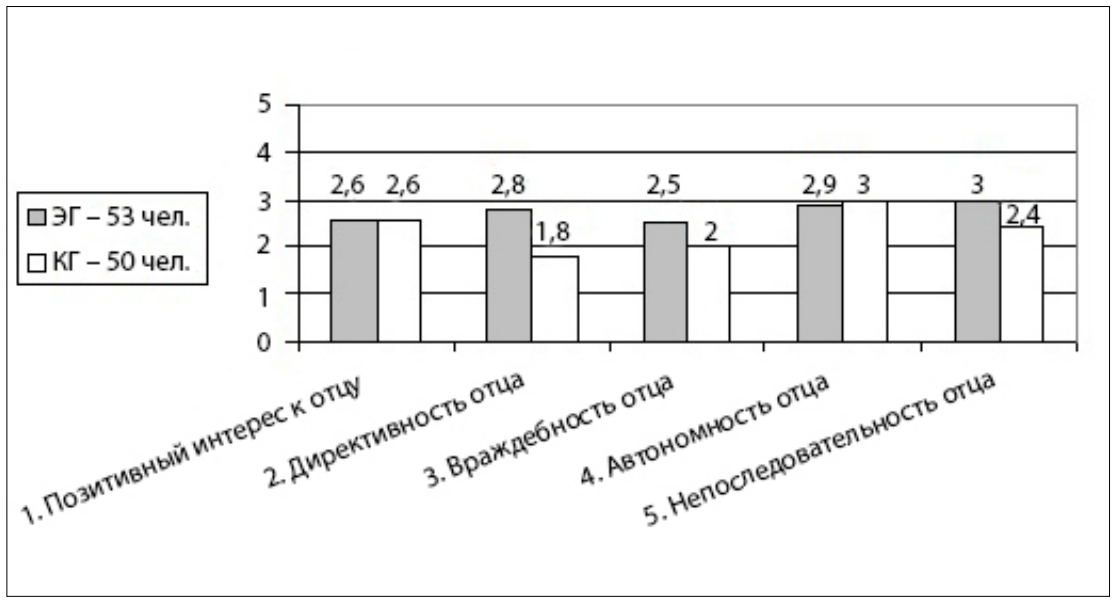

Рисунок 2. Показатели образа отца у левушек экспериментальной и контрольной групп

Figure 2. Indices of a father's image among girls from experimental and control groups 
Результаты, полученные по методике «Семейная социограмма» Э. Г. Эйдемиллера и О.В. Черемисина, представлены ниже в таблице 4.

Таблица 4. Характер межличностных отношений Аочери с отцом у Аевушек экспериментальной и контрольной групп

Table 4. Interpersonal relationships between girls from experimental and control groups and their fathers

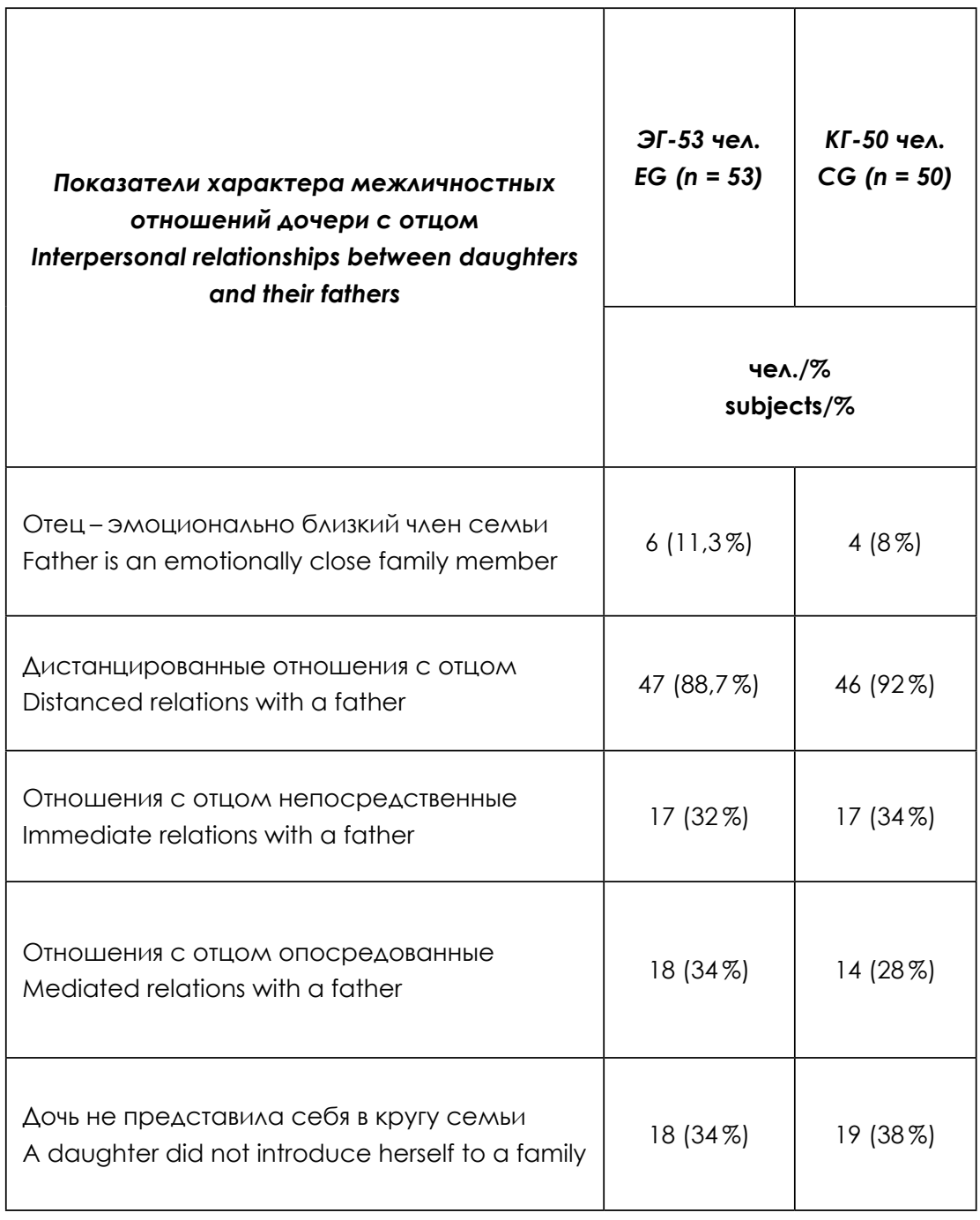


Результаты, полученные по методике самооценки «Я в отношениях с мужчинами в глазах других людей», представлены ниже в таблице 5.

Таблица 5. Оценка своего положения Аевушками обеих групп в отношениях с мужчинами глазами Аругих ^юАей

Table 5. Girls' assessment of their position in relationships with men in others' eyes

\begin{tabular}{|c|c|c|}
\hline $\begin{array}{c}\text { Оценка своего положения Аевушками } \\
\text { в отношениях с мужчинами глазами Аругих } \\
\text { ^юАей }\end{array}$ & $\begin{array}{l}\text { ЭГ-53 чеА. } \\
E G(n=53)\end{array}$ & $\begin{array}{l}K Г-50 \text { чел. } \\
C G(n=50)\end{array}$ \\
\hline with men in others' eyes & \multicolumn{2}{|c|}{$\begin{array}{c}\text { чел./\% } \\
\text { subjects/\% }\end{array}$} \\
\hline $\begin{array}{l}0 \text { - «3Аесь нет такой фрразы, которая обо мне» } \\
0 \text { - "There is no phrase about me" }\end{array}$ & $10(18,9 \%)$ & 27 (54\%) \\
\hline $\begin{array}{l}1 \text {-«Она хорошая девочка, но ей не везет } \\
\text { в ^юбви» } \\
1 \text { - "She's a good girl but she's unlucky in love" }\end{array}$ & $15(28,3 \%)$ & $6(12 \%)$ \\
\hline $\begin{array}{l}\text { 2- «Она п^охая Аевочка, но ее ^юбит } \\
\text { хороший парень» } \\
\text { 2- "She's a bad girl but she's loved by a good } \\
\text { guy" }\end{array}$ & $4(7,5 \%)$ & 0 \\
\hline $\begin{array}{l}\text { 3- «Она п^охая Аевочка, но парни за ней } \\
\text { табуном ходят» } \\
3 \text { - "She's a bad girl but there are a lot of guys } \\
\text { around her" }\end{array}$ & $2(3,8 \%)$ & 0 \\
\hline $\begin{array}{l}\text { 4-«Она хорошая Аевочка и пользуется } \\
\text { повышенным вниманием парней» } \\
4 \text { - "She's a good girl and enjoys the attention } \\
\text { of guys" }\end{array}$ & $6(11,3 \%)$ & 2 (4\%) \\
\hline $\begin{array}{l}\text { 5- «Она хорошая Аевочка и Аружит } \\
\text { с таким же хорошим парнем» } \\
5 \text { - "She is a good girl and her guy is good as } \\
\text { well" }\end{array}$ & $16(30,2 \%)$ & 15 (30\%) \\
\hline
\end{tabular}


Результаты, полученные с помощью методики оценки отношений дочери с родным отцом и его вовлеченности в воспитание по 10-балльной шкале, представлены ниже в таблице 6.

Таблица 6. Оценка Аочерьми своих Отношений с родным Отцом и его вовлеченности в воспитание

Table 6. Daughters' assessment of their relationships with their fathers and their involvement in upbringing

\begin{tabular}{|c|c|c|}
\hline $\begin{array}{c}\text { Показатели (средние значения) } \\
\text { Characteristics (mean scores) }\end{array}$ & $\begin{array}{l}\text { ЭГ-53 чеА. } \\
E G(n=53)\end{array}$ & $\begin{array}{l}K \Gamma-50 \text { чел. } \\
C G(n=50)\end{array}$ \\
\hline $\begin{array}{l}\text { Оценка дочерью вовлеченности отца в ее } \\
\text { воспитание } \\
\text { A daughter's assessment of her father's } \\
\text { involvement in her upbringing }\end{array}$ & 5,3 & 6,9 \\
\hline $\begin{array}{l}\text { Оценка Аочерью отношений с отцом } \\
\text { A daughter's assessment of relationships with her } \\
\text { father }\end{array}$ & 5,5 & 7,2 \\
\hline
\end{tabular}

\section{Обсуждение результатов}

Полученные нами результаты показывают следующее:

1) девушки с любовной аддикцией чаще воспитывались в неполных семьях, чем девушки, не имевшие любовной зависимости (различия достоверны, $\mathrm{U}=965,0$ при $\mathrm{p}=0,008)$;

2) девушки с любовной зависимостью имели больше опыта любовного общения с мужчинами (это касается числа партнеров и длительности отношений), чем их сверстницы, не имевшие любовной зависимости (различия достоверны; для показателя числа партнеров $U=1026,0$ при $p=0,030$; для показателя длительности отношений $U=855,0$ при $p=0,002)$;

3) девушки - любовные аддикты более продолжительно страдали после разрыва отношений с партнером, чем их сверстницы, не имевшие любовной зависимости (что закономерно; различия достоверны $U=280,5$ при $p=0,000$ );

4) причины разрыва любовных отношений, указанные девушками с любовной зависимостью и без нее, различны: у первых они преимущественно свидетельствуют о «плохом» обращении с ними их партнеров, у вторых - о неоправданных парнями ожиданиях девушек («бабник»; «не знал, чего хочет») и вмешательстве внешних факторов («мать», «расстояние»);

5) девушки обеих групп значительно различались по показателям межличностной любовной зависимости: у девушек - любовных аддиктов 


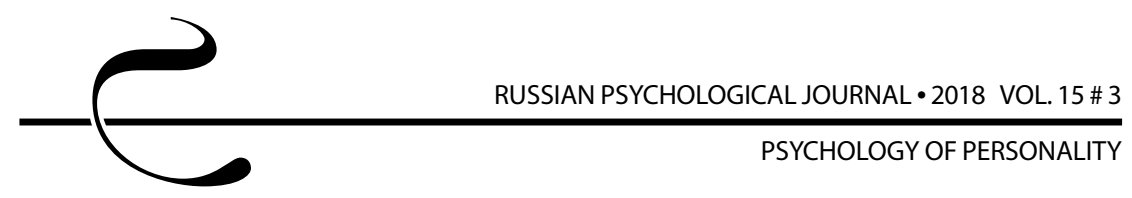

значительно выше уровень эмоциональной опоры на других (различия достоверны; $U=240,0$ при $p=0,000$ ), хотя при этом они несколько превосходят группу девушек без любовной зависимости по стремлению к автономии; в целом общий уровень межличностной любовной зависимости у девушек с любовной аддикцией достоверно выше, чем у их сверстниц, не имеющих любовной аддикции (различия достоверны; $U=658,0$ при $\mathrm{p}=0,000)$;

6) образ отца в глазах дочерей, страдающих любовной аддикцией, менее позитивен, чем в глазах их сверстниц, не имеющих любовной зависимости, по показателям директивности, враждебности и непоследовательности отца (различия достоверны, $U=885,5$ при $\mathrm{p}=0,003$ );

7) оценка своего положения девушками в отношениях с мужчинами глазами других людей свидетельствует о том, что в группе девушек с любовной аддикцией гораздо больше тех, которые «хорошие девочки, но им не везет в любви», а также тех, кто, будучи хорошими, пользуется повышенным вниманием парней (различия достоверны; $U=983,0$ при $p=0,018$ );

8) оценки дочерьми вовлеченности отцов в их воспитание и качества межличностных отношений с ними у девушек - любовных аддиктов достоверно ниже, чем у девушек, не имеющих любовной зависимости.

Корреляционный анализ данных показал следующие взаимосвязи показателей:

1) чем благополучнее (традиционней) состав семьи девушек обеих групп, тем отчетливей они ощущают позитивный интерес к отцу;

2) чем позитивнее отношения дочери с отцом в обеих группах, тем выше вовлеченность отца в воспитание дочери; но вместе с тем: чем выше вовлеченность отца, тем более выражена непоследовательность применяемых им воспитательных мер (эта закономерность отчасти отражает проблему современного отцовства - родительскую некомпетентность);

3) показатель враждебности отца у девушек - любовных аддиктов согласуется с показателями неуверенности в себе $(r=0,368$, при $p=0,007)$ и стремлением к автономии $(r=0,366$, при $p=0,007)$. То есть чем враждебнее отец, тем в большей степени дочь не уверена в себе, но при этом она сильнее стремится к автономии;

4) чем более выражена неуверенность девушки в себе, тем более отдаленные от семейного круга лица признаются ею наиболее эмоционально близкими (ЭГ: $r=-0,355$, при $p=0,009 ;$ КГ: $r=-0,288$, при $p=0,042)$; особенно это выражено у девушек - любовных аддиктов;

5) чем более директивным стилем воспитания запомнился отец, тем более выражена потребность в эмоциональной опоре на других у девушек обеих групп (ЭГ: $r=0,434$, при $\mathrm{p}=0,001 ; \mathrm{KГ:} r=0,463$, при $\mathrm{p}=0,001)$; 
6) девушки обеих групп с высокими показателями межличностной зависимости и эмоциональной опоры на других дольше находятся в любовных отношениях с партнерами. В то же время длительность страданий после разрыва отношений у девушек обеих групп сильно согласуется с выраженностью любовной аддикции (ЭГ: $r=0,918$, при $\mathrm{p}=0,000 ; \mathrm{KГ:} r=0,478$, при $\mathrm{p}=0,000$ ). Иначе говоря, чем выше показатель любовной аддикции, тем дольше продолжаются страдания после расставания с партнером, что закономерно;

7) опыт общения с мужчинами у девушек - любовных аддиктов тесно прямо согласуется с непоследовательностью отца $(r=0,539$, при $p=0,000)$, его директивностью $(r=0,812$, при $p=0,000)$, позитивным интересом дочери к отцу $(r=0,389$, при $p=0,004)$ и ее неуверенностью в себе $(r=0,457$, при $\mathrm{p}=0,001)$. Иначе говоря, чем больше опыта общения с мужчинами у девушек с любовной аддикцией, тем больше было непоследовательности в применяемых отцом мерах воспитания, тем выше его директивность в отношениях с дочерью и тем выше неуверенность девушки в себе;

8) показатель длительности отношений с мужчинами у девушек - любовных аддиктов прямо коррелирует с переменными длительности страданий после расставания $(r=0,768$, при $p=0,000)$ и с выраженностью любовной аддикции $(r=0,429$, при $p=0,001)$, и отрицательно - с позитивным интересом к отцу ( $r=-0,377$, при $p=0,005)$. Следовательно, чем дольше длились отношения с партнерами, тем больше страданий после расставания испытывает девушка, тем сформированней у нее любовная аддикция, и тем меньше позитивного интереса со стороны отца она ощущала. В контрольной группе девушек длительность отношений с партнером тесно прямо коррелирует с враждебностью отца $(r=0,422$, при $p=0,002)$ - чем враждебнее отношения отца к дочери, тем продолжительнее девушка поддерживает мучительные любовные отношения с партнером (вероятно, эти девушки привыкли терпеть боль от общения с отцом и поэтому дольше выдерживают ее в общении с любимыми);

9) показатель любовной аддикции отражает тесные корреляции только по данным экспериментальной группы. А именно: прямо - со шкалами зависимости $(r=0,776$, при $p=0,000)$ и эмоциональной опоры на других $(r=0,860$, при $\mathrm{p}=0,000)$, и обратно - со шкалами позитивного интереса $(r=-0,814$, при $p=0,000)$ и неуверенности в себе $(r=-0,406$, при $p=0,003)$. Это означает, что чем сильнее у девушек межличностная зависимость в целом и потребность в эмоциональной опоре на другого в частности, тем слабее позитивный интерес отца к дочери и тем слабее ее уверенность в себе, но выше уровень любовной аддикции;

10) если показатель межличностной зависимости у девушек - любовных аддиктов (экспериментальная группа) тесно отрицательно согласуется с позитивным интересом отца $(r=-0,731$, при $p=0,000)$, то у девушек контрольной 


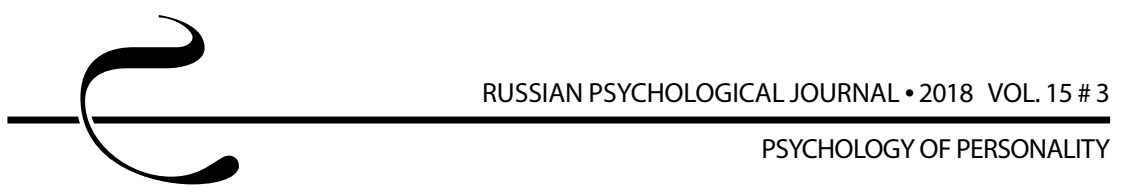

группы он тесно прямо коррелирует с его директивностью $(r=0,543$, при $\mathrm{p}=0,000)$ и враждебностью $(r=0,496$, при $\mathrm{p}=0,000)$. Иначе говоря, В группе девушек с любовной аддикцией межличностная зависимость выше у тех из них, которые меньше ощущали позитивный интерес к отцу (почти у половины из них кровные отцы лишь эпизодически участвовали или вовсе не принимали участия в воспитании дочери), а в контрольной группе девушек межличностная зависимость оказалась выше у тех, чьи отцы проявляли директивность и враждебность, участвуя в воспитании дочери;

11) для обеих групп характерна согласованность возраста и межличностной зависимости. Но по экспериментальной группе эта зависимость положительная $(r=0,730$, при $p=0,000)$, а по контрольной - отрицательная $(r=-0,284$, при $\mathrm{p}=0,046)$. Иными словами, чем старше девушка, не страдающая любовной аддикцией, тем меньше ее межличностная зависимость. В то же время у девушек-любовных аддиктов с возрастом межличностная зависимость нарастает.

Таким образом, можно сделать выводы о том, что обследованным нами девушкам с любовной аддикцией, по сравнению с девушками, не имеющими ее, свойственны следующие характерные особенности:

а) достоверно более высокий уровень эмоциональной опоры на других;

б) достоверно более высокий уровень стремления к автономии;

в) они достоверно реже воспитываются в традиционных полных семьях;

г) они более длительное время поддерживают мучительные любовные отношения и дольше страдают после расставания с партнерами.

Что касается участия родного отца в воспитании девушек - любовных аддиктов, по сравнению с отцами девушек, не имеющих любовной аддикции, то девушки с любовной аддикцией:

а) достоверно чаще лишены возможности полноценного общения с родными отцами;

б) вовлеченность родного отца в процесс воспитания оценивают достоверно ниже, чем девушки без любовной аддикции;

в) достоверно ниже, чем девушки без любовной аддикции, оценивают качество отношений с родным отцом.

Отношения девушек - любовных аддиктов с собственными отцами достоверно чаще характеризуются директивностью отца, его непоследовательностью и враждебностью по сравнению с девушками, не страдающими любовной аддикцией. При этом у девушек обеих групп позитивный интерес к отцу выражен в равной степени. Но если учесть, что из ЭГ в полной семье воспитывались лишь 25 девушек (47,2 \%), тогда как из КГ - 34 девушки (68 \%), то вывод о заметной роли отца («физически отсутствующего», «безучастного» или «неадекватного в своем участии») в формировании любовной аддикции дочери представляется вполне обоснованным. 
В заключение, как практические социальные психологи, отметим, что любовь - самое сильное чувство, и для многих девушек - очень страстное и мучительное. Науке известно, что психология человеческой любви и психология химической зависимости имеют много общего как процессы, имеющие начало (первый опыт), динамику и исход [4, 8, 36]. Мы попытались охарактеризовать особенности и понять причину любовных страданий девушек в возрасте от 16 до 19 лет и усмотрели их в характере отношений дочерей - любовных аддиктов с родными отцами. Из полученных нами результатов следует, что психологическая коррекция любовной аддикции девушек на основе названных выше программ является симптоматическим подходом в работе с этим расстройством. Если задаться целью внедрения в практику социально-психологического обслуживания населения профилактических моделей любовной аддикции девушек, то для этого необходимо усилить психологическое просвещение населения, в частности, в системе школьного образования организовать Школы для отцов, в системе социальной защиты населения - «Папины Университеты» для отцов, имеющих дочерей; шире использовать СМИ; индивидуальную работу со случаями любовной аддикции несовершеннолетних девушек сочетать с семейным консультированием и семейной психотерапий. На наш взгляд, акцент на профилактике любовной аддикции у новых поколений российских женщин перспективнее разработок новых, даже более эффективных, чем уже имеющиеся, моделей ее коррекции.

\section{Литература}

1. Егоров А. Ю. Любовные аддикции // Вестник психиатрии и психологии Чувашии. 2015. Т. 11, № 2. С. 64-81.

2. Ивахнова И. Д. Любовная аддикция как социально-психологический феномен // Практика заботы в современном обществе: Материалы Всерос. научно-практической конференции. Саратов: Саратовский источник, 2017. С. 104-107.

3. Москаленко В.Д. Когда любви слишком много: Профилактика любовной зависимости. М.: Психотерапия, 2006. 224 с.

4. Пил С., Бродски А. Любовь и зависимость. М.: Институт общегуманитарных исследований, 2005. 384 с.

5. Уайнхолд Б., Уайнхолд Дж. Освобождение от созависимости. М.: Независимая фирма «Класс», 2002. 224 с.

6. Sophia E. C., Tavares H., Berti M. P., Pereira A. P., Lorena A., Mello C., Gorenstein C., Zilberman M. L. Pathological Love: Impulsivity, Personality, and Romantic Relationship // CNS Spectrums. 2009. Vol. 14, Issue 5. P. 268-274. DOI: $\underline{10.1017 / \text { S1092852900025438 }}$ 
7. Каст В. Отцы - дочери, матери - сыновья. Путь от отцовского и материнского комплексов к собственной личностной идентичности. М.: Дипак, 2016. 184 с.

8. Норвуд Р. Женщины, которые любят слишком сильно. М.: Добрая книга, 2013. 352 c.

9. Шалаева Е. П. Исследование любовной аддикции дочерей в связи с отцовской депривацией // Современные тенденции развития науки и технологий. 2017. № 3-10. С. 131-135.

10. Etchegoyen A., Trowell J. The importance of fathers. A Psychoanalytic Reevaluation. New York: Taylor and Francis, 2002. 272 p.

11. Suh G. W., Fabricius W. V., Stevenson M. M., et al. Effects of the interparental relationship on adolescents' emotional security and adjustment: The important role of fathers // Developmental Psychology. 2016. Vol. 52 (10). P. 1666-1678. DOI: $10.1037 /$ dev0000204

12. Милюкова Е. В. Формирование психологических компонентов родительской любви: дисс. ... канд. психол. наук. Курган, 2005. 191 с.

13. Овчарова Р. В., Токарева Ю. А. Отцовство как ценность и сфера самореализации личности // Психологические проблемы современной семьи: материалы IV Международной научной конференции / под ред. Е. И. Захаровой, О. А. Карабановой. М.: Изд-во МГУ, 2009. С. 484-488.

14. Севастьянова У. Ю. Психолого-акмеологические факторы развития продуктивного отцовского отношения: дисс. ... канд. психол. наук. Кострома, 2015. 180 с.

15. Fisher H. E., Brown L. L., Aron A., Strong G., Mashek D. Reward, Addiction, and Emotion Regulation Systems Associated With Rejection in Love // Journal of Neurophysiology. 2010. Vol. 104, Issue 1. P. 51-60. DOI: 10.1152 / jn.00784.2009

16. Асеева А.Д. Социально-психологические аспекты зависимого поведения в межличностных отношениях в юношеском возрасте: дисс. ... канд. психол. наук. Курск, 2014. 210 с.

17. Богатырева О. В., Мусихина А. Л., Панфилов П. В. Образ желаемого партнера и отношений в представлении эмоционально зависимых девушек // Актуальные проблемы психологической безопасности человека в современном обществе. 2010. № 1. С. 32-42.

18. Смирнов А. В. Базовые психологические компоненты аддиктивного поведения в структуре интегральной индивидуальности: дисс. ... д-ра психол. наук. Екатеринбург, 2015. 489 с.

19. Шапаренко Е. Ю., Фальковский Г. В. Рефлексы любви и счастья. М.: АСТ, 2016. 192 c.

20. Фромм Э. Искусство любить. М.: АСТ, 2014. 221 с. 
21. Черникова Н. В. Психология и психотерапия химической и эмоциональной зависимости. М.: Изд-во МГИ им. Е. Р. Дашковой, 2012. 129 с.

22. Юнг К. Г. Конфликты детской души. М.: Канон, 1997. 336 с.

23. de Looze M., Constantine N. A., Jerman P., Vermeulen-Smit E., ter Bogt T. ParentAdolescent Sexual Communication and Its Association With Adolescent Sexual Behaviors: A Nationally Representative Analysis in the Netherlands // The Journal of Sex Research. 2015. Vol. 52, Issue 3. P. 257-268. DOI: 10.1080/00224499.2013.858307

24. Luo Y., Xiang Z., Zhang H., Wang Z. Protective factors for depressive symptoms in adolescents: Interpersonal relationships and perceived social support // Psychology in the Schools. 2017. Vol. 54, Issue 8. P. 808-820. DOI: 10.1002/pits.22033

25. Smith A., Pedersen E. J., Forster D. E., McCullough M. E., Lieberman D. Cooperation: The roles of interpersonal value and gratitude // Evolution and Human Behavior. 2017. Vol. 38, Issue 6. P. 695-703. DOI: 10.1016/j.evolhumbehav. 2017.08.003

26. Битmи М. Спасать или спасаться? Как избавиться от желания постоянно опекать других и начать думать о себе. М.: Эксмо, 2015. 384 с.

27. Лазаренко Д. В. Психолого-педагогическая профилактика склонности к аддиктивному поведению студентов вуза: дисс. ... канд. психол. наук. Кемерово, 2016. 201 с.

28. Цветкова Н. А., Четверик М. А. Об актуальности формирования представлений девушек 16-17 лет о самосохранительном поведении // Психолого-социальная работа в современном обществе: проблемы и решения: Материалы XIII Международной научно-практической конференции. СПб.: Изд-во СПбГИПСР, 2015. С. 192-195.

29. Mityaeva A. M., Fomina S. N., Tsvetkova N. A., Rybakova A. I., Gedulyanova N. S., Khovanskaya E. A. Psychological counseling strategies for women regarding their level of fulfillment of need for personal development // The Turkish Online Journal of Design, Art and Communication. 2017. Vol. 7, S-APRLSPCL. P. 3263-3283.

30. Менделевич В. Д., Зобин М. Н. Аддиктивное влечение. М.: МЕДпресс-информ, 2012. 264 c.

31. Langley C. Father Knows Best: Paternal Presence and Sexual Debut in AfricanAmerican Adolescents Living in Poverty // Family Process. 2016. Vol. 55, Issue 1. P. 155-170. DOI: 10.1111/famp.12125

32. Sadikaj G., Moskowitz D. S., Zuroff D. C. Intrapersonal variability in interpersonal perception in romantic relationships: Biases and accuracy // Journal of Research in Personality. 2017. Vol. 69. P.67-77. DOI: 10.1016/j.jrp.2016.06.011

33. Плотников С. Г., Галимбиевская Ю. Д., Фастова В. А. Взаимосвязь детско-родительских отношений с выбором брачного партнера // Наука XXI века: теория, практика и перспективы: материалы Между- 


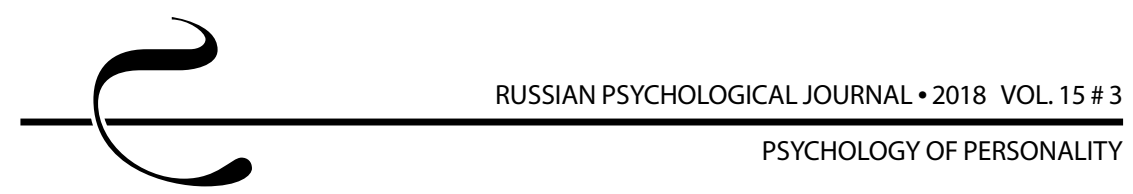

народной научно-практической конференции. Уфа: ОМЕГА САЙНС, 2015. C. 285-287.

34. Григорова Т. П. Деструктивная привязанность к партнеру во взрослом возрасте и совладание с ее проявлениями: дисс. ... канд. психол. наук. Кострома, 2015. 166 с.

35. Латыпов Н. Н. Метафизика любви + страсть глазами нейробиолога. М.: ACT, 2015. 206 c.

36. Егоров А. Ю. Нехимические зависимости:монография. СПб.: Речь, 2007. 190 с.

37. Макушина О. П. Опросник межличностной зависимости. Р. Гиршфильд. Адаптация О.П. Макушиной //Психология общения. Энциклопедический словарь / под общ. ред. А. А. Бодалева. М.: Когито-Центр, 2011. С. 600.

38. Вассерман Л. И., Горькова И. А., Ромицына Е. Е. Психологическая методика «Подростки о родителях» и ее практическое применение. 3-е изд., доп. и перераб. СПб.: ФАРМиндекс, 2001. 68 с.

39. Олифирович Н. И., Зинкевич-Куземкина Т. А., Велента Т. Ф. Психология семейных кризисов. СПб.: Речь, 2006. 360 с.

\section{References}

1. Egorov A. Yu. Love addictions. Vestnik psikhiatrii i psikhologii Chuvashii-The Bulletin of Chuvash Psychiatry and Psychology, 2015, V. 11, no. 2, pp. 64-81 (in Russian).

2. Ivakhnova I. D. Lyubovnaya addiktsiya kak sotsial'no-psikhologicheskii fenomen [Love addiction as a socio-psychological phenomenon]. Praktika zaboty v sovremennom obshchestve: Materialy Vseros. nauchnoprakticheskoi konferentsii [Proc. the All-Russian Theoretical and Practical Conference "Practice of care in modern society"]. Saratov, Saratovskii istochnik, 2017, pp. 104-107.

3. Moskalenko V. D. Kogda lyubvi slishkom mnogo: Profilaktika lyubovnoi zavisimosti [When there is too much love: Preventing love addiction]. Moscow, Psikhoterapiya Publ., 2006. 224 p.

4. Peele S., Brodsky A. Love and Addiction. New York, Taplinger, 1975 (Russ. ed.: Pil S., Brodski A. Lyubov' i zavisimost'. Moscow, Humanities Institute Publ., 2005. 384 p.).

5. Weinhold B., Weinhold J. Breaking free of the co-dependency trap (Russ. ed.: Uainkhold B., Uainkhold Dzh. Osvobozhdenie ot sozavisimosti. Moscow, Klass Publ., 2002. 224 p.).

6. Sophia E. C., Tavares H., Berti M. P., Pereira A. P., Lorena A., Mello C., Gorenstein C., Zilberman M. L. Pathological love: Impulsivity, personality, and romantic relationship. CNS Spectrums, 2009, V. 14, Issue 5, pp. 268-274. DOI: $10.1017 /$ S1092852900025438 
7. Kast V. Father-daughter, mother-son: Freeing ourselves from the complexes that bind us. Element books, 1997 (Russ. ed.: Kast V. Ottsy-docheri, materi synov'ya. Put' ot ottsovskogo i materinskogo kompleksov k sobstvennoi lichnostnoi identichnosti. Moscow, Dipak Publ., 2016. 184 p.).

8. Norwood R. Women who love too much. Los Angeles, CA, Jeremy P. Tarcher, 1985 (Russ. ed.: Norvud R. Zhenshchiny, kotorye lyubyat slishkom sil'no. Moscow, Dobraya kniga Publ., 2013. 352 p.).

9. Shalaeva E. P. Studying love addiction in daughters in connection with paternal deprivation. Sovremennye tendentsii razvitiya naukiitekhnologii-Modern Trends in the Development of Science and Technology, 2017, no. 3-10, pp. 131-135 (in Russian).

10. Etchegoyen A., Trowell J. The importance of fathers. A Psychoanalytic Reevaluation. New York, Taylor and Francis, 2002. 272 p.

11. Suh G. W., Fabricius W. V., Stevenson M. M., et al. Effects of the interparental relationship on adolescents' emotional security and adjustment: The important role of fathers. Developmental Psychology, 2016, V. 52 (10), pp. 1666-1678. DOI: 10.1037/dev0000204

12. Milyukova E. V. Formirovanie psikhologicheskikh komponentov roditel'skoi lyubvi [Forming psychological components of parental love]. Diss. Cand. Sci. (Psych.). Kurgan, 2005. 191 p.

13. Ovcharova R. V., Tokareva Yu. A. Ottsovstvo kak tsennost' i sfera samorealizatsii lichnosti [Fatherhood as a value and the field of personal self-actualization]. Materialy IV Mezhdunarodnoi nauchnoi konferentsii "Psikhologicheskie problemy sovremennoi sem'i" [Proc. the IV International Scientific Conference "Psychological problems of modern family"]. Moscow, Moscow State University Publ., 2009, pp. 484-488.

14. Sevast'yanova U. Yu. Psikhologo-akmeologicheskie faktory razvitiya produktivnogo ottsovskogo otnosheniya [Psychological and acmeological factors for productive paternal relations]. Diss. Cand. Sci. (Psych.). Kostroma, 2015. 180 p.

15. Fisher H. E., Brown L. L., Aron A., Strong G., Mashek D. Reward, addiction, and emotion regulation systems associated with rejection in love. Journal of Neurophysiology, 2010, V. 104, Issue 1, pp. 51-60. DOI: 10.1152/jn.00784.2009

16. Aseeva A. D. Sotsial'no-psikhologicheskie aspekty zavisimogo povedeniya $v$ mezhlichnostnykh otnosheniyakh $v$ yunosheskom vozraste [Social and psychological aspects of dependent behavior in interpersonal relations in adolescence]. Diss. Cand. Sci. (Psych.). Kursk, 2014. 210 p.

17. Bogatyreva O. V., Musikhina A. L., Panfilov P. V. The image of the desired partner and relations in representations of emotionally dependent girls. Aktual'nye problemy psikhologicheskoi bezopasnosticheloveka v sovremennom obshchestve - Current Problems of Psychological Security of a Person in Modern Society, 2010, no. 1, pp. 32-42 (in Russian). 
18. Smirnov A. V. Bazovye psikhologicheskie komponenty addiktivnogo povedeniya $v$ strukture integral'noi individual'nosti [Basic psychological components of addictive behavior in the structure of integral individuality]. Diss. Cand. Sci. (Psych.). Ekaterinburg, 2015. 489 p.

19. Shaparenko E. Yu., Fal'kovskii G. V. Refleksy lyubvi i schast'ya [Reflexes of love and happiness]. Moscow, AST Publ., 2016. 192 p.

20. Fromm E. The art of loving. London, Thorsons, 1995 (Russ. ed.: Fromm E. Iskusstvo lyubit'. Moscow, AST Publ., 2014. 221 p.).

21. Chernikova N. V. Psikhologiya i psikhoterapiya khimicheskoi i emotsional'noi zavisimosti [Psychology and psychotherapy of chemical and emotional dependence]. Moscow, MHI Publ., 2012. 129 p.

22. Jung C. G. The conflicts in the child's souls (Russ. ed.: Yung K. G. Konflikty detskoi dushi. Moscow, Kanon Publ., 1997. 336 p.).

23. de Looze M., Constantine N. A., Jerman P., Vermeulen-Smit E., ter Bogt T. Parent-adolescent sexual communication and its association with adolescent sexual behaviors: A nationally representative analysis in the Netherlands. The Journal of Sex Research, 2015, V. 52, Issue 3, pp. 257-268. DOI: $10.1080 / 00224499.2013 .858307$

24. Luo Y., Xiang Z., Zhang H., Wang Z. Protective factors for depressive symptoms in adolescents: Interpersonal relationships and perceived social support. Psychology in the Schools, 2017, V. 54, Issue 8, pp. 808-820. DOl: 10.1002/pits.22033

25. Smith A., Pedersen E. J., Forster D. E., McCullough M. E., Lieberman D. Cooperation: The roles of interpersonal value and gratitude. Evolution and Human Behavior, 2017, V. 38, Issue 6, pp. 695-703. DOI: 10.1016/j.evolhumbehav. 2017.08.003

26. Beattie M. Codependent no more: How to stop controlling others and start caring for yourself. Walker and Company, 1987 (Russ. ed.: Bitti M. Spasat' ili spasat'sya? Kak izbavit'sya ot zhelaniya postoyanno opekat' drugikh i nachat' dumat'o sebe. Moscow, Eksmo Publ., 2015. 384 p.).

27. Lazarenko D. V. Psikhologo-pedagogicheskaya profilaktika sklonnosti $k$ addiktivnomu povedeniyu studentov vuza [Psychological and pedagogical prevention of tendency toward addictive behavior among university students]. Diss. Cand. Sci. (Psych.). Kemerovo, 2016. 201 p.

28. Tsvetkova N. A., Chetverik M. A. Ob aktual'nosti formirovaniya predstavlenii devushek 16-17 let o samosokhranitel'nom povedenii [Urgency of forming the ideas of self-preservation behavior among 16-19-year-old girls]. Materialy XIII Mezhdunarodnoi nauchno-prakticheskoi konferentsii "Psikhologosotsial'naya rabota vsovremennom obshchestve: problemy i resheniya" [Proc. the 13th International Theoretical and Practical Conference "Psycho-social work in modern society: problems and solutions"]. St. Petersburg, St. Petersburg State Institute of Psychology and Social Work Publ., 2015, pp. 192-195. 
29. Mityaeva A. M., Fomina S. N., Tsvetkova N. A., Rybakova A. I., Gedulyanova N. S., Khovanskaya E. A. Psychological counseling strategies for women regarding their level of fulfillment of need for personal development. The Turkish Online Journal of Design, Art and Communication, 2017, V. 7, S-APRLSPCL, pp. 3263-3283.

30. Mendelevich V. D., Zobin M. N. Addiktivnoe vlechenie [Addictive drive]. Moscow, MEDpress-inform Publ., 2012. 264 p.

31. Langley C. Father knows best: Paternal presence and sexual debut in AfricanAmerican adolescents living in poverty. Family Process, 2016, V. 55, Issue 1, pp. 155-170. DOI: $10.1111 /$ famp.12125

32. Sadikaj G., Moskowitz D. S., Zuroff D. C. Intrapersonal variability in interpersonal perception in romantic relationships: Biases and accuracy. Journal of Research in Personality, 2017, V. 69, pp. 67-77. DOI: 10.1016/j.jrp.2016.06.011

33. Plotnikov S. G., Galimbievskaya Yu. D., Fastova V. A. Vzaimosvyaz' detskoroditel'skikh otnoshenii s vyborom brachnogo partnera [Associations between child-parent relations and the choice of a marriage partner]. Materialy Mezhdunarodnoi nauchno-prakticheskoi konferentsii "Nauka XXI veka: teoriya, praktika i perspektivy" [Proc. the International Theoretical and Practical Conference "Science of the 20th century: Theory, practice, and prospects"]. Ufa, Omega Sains Publ., 2015, pp. 285-287.

34. Grigorova T. P. Destruktivnaya privyazannost' $k$ partneru vo vzroslom vozraste i sovladanie s ee proyavleniyami [Destructive attachment to a partner in adulthood and coping with its manifestations]. Diss. Cand. Sci. (Psych.). Kostroma, 2015. 166 p.

35. Latypov N. N. Metafizika lyubvi + strast' glazami neirobiologa [Metaphysics of love + passion through a neurobiologist's eyes]. Moscow, AST Publ., 2015. 206 p.

36. Egorov A. Yu. Nekhimicheskie zavisimosti: monografiya [Non-chemical addictions]. St. Petersburg, Rech' Publ., 2007. 190 p.

37. Makushina O. P. The Interpersonal Dependency Inventory (R. Hirschfeld): O. P. Makushina's modification. In: A. A. Bodalev (ed.) Psikhologiya obshcheniya. Entsiklopedicheskii slovar' [Psychology of communication. The encyclopedic dictionary]. Moscow, Kogito-Tsentr, 2011.600 p.

38. Vasserman L. I., Gor'kova I. A., Romitsyna E. E. Psikhologicheskaya metodika "Podrostki o roditelyakh" i ee prakticheskoe primenenie [The Teenagers About Parents psychological technique and its practical application]. St. Petersburg, FARMindeks Publ., 2001.68 p.

39. Olifirovich N. I., Zinkevich-Kuzemkina T. A., Velenta T. F. Psikhologiya semeinykh krizisov [Psychology of family crises]. St. Petersburg, Rech' Publ., 2006. 360 p. 